\title{
"ALERT VILLAGE PROGRAM" AS AN EFFORT TO REDUCING MATERNAL MORTALITY CASE IN BREBES, CENTRAL JAVA
}

\author{
Nuzulul Fika Aulia \\ Faculty of Social Sciences, Universitas Negeri Semarang
}

\begin{abstract}
Background: Brebes Regency had the highest maternal mortality rates in Central Java for four consecutive years, from 2014 to 2017. The high maternal mortality rate prompted the formation of the "alert village program" to reduce the risk of maternal death. This study aimed to analyze the implementation of "alert village program" and the impact of the program on pregnant women.

Subjects and Method: This was a qualitative study conducted in Brebes Regency, Central Java. Key informants for this study were midwives, pregnant mothers at high risk pregnancy, husband, family member, and neighbor. The data were collected by literature review, observation, and in-depth interview.

Results: The "alert village program" increased knowledge of husband, family member, and community about the risks of pregnancy and childbirth. Through the "alert village program", every layer of society had a role to maintain the health of pregnant women during pregnancy until childbirth. Parties that played a role in the "alert village program" were (1) husband (2) family member (3) neighbors or local community (4) religious leaders, and (5) midwife or health personnel.

Conclusion: "Alert village program" has been implemented as an effort to involve all parties in the society in order to have knowledge in safe motherhood and to supervise the pregnant mothers so that they remain safe and are able to access health facility so as to reduce the risk of maternal death.
\end{abstract}

Keywords: "Alert village program", pregnant mother, maternal mortality, Brebes, Central Java

\section{Correpondence:}

Nuzulul Fika Aulia. Faculty of Social Sciences, Universitas Negeri Semarang, Semarang, Central Java. 